\title{
The Mediating Effect of Problem-focused Coping on the Relationship between Job Insecurity and Impression Management
}

\author{
Ananda Nadya Putri, Debora Eflina Purba* \\ Faculty of Psychology, Universitas Indonesia, Depok, 16424, Indonesia \\ *E-mail: eflina@ui.ac.id
}

\begin{abstract}
The study aimed to investigate the mediating effect of problem-focused coping on the relationship between job insecurity and impression management. Drawing on Transactional Stress Theory to explain the mediation model, we argued that perceived job insecurity would activate individual's problem-focused coping, and in turn, would lead to high levels of impression management. Data were collected among employees from nine organisations in Jakarta $(\mathrm{N}=286)$ and were analysed using Hayes's PROCESS macro on regression analysis of SPSS version 20. The results showed that the indirect effect of job insecurity and impression management via problem-focused coping was significant. However, contrary to our expectation, we found that perceived job insecurity weakened individuals' ability to activate problemfocused coping, and in turn led to reduced willingness to perform impression management.
\end{abstract}

Keywords: coping, impression management, job insecurity, problem-focused coping, transactional stress theory

\section{Introduction}

The instability of the economic conditions that hit the world seems to have a bad impact on employees in Indonesia. For instance, the fall in oil prices in 2016 lead the oil companies into a crisis; wherein many companies were enforced to reduce their employees (Daeng, 2016). Furthermore, globalisation and ASEAN Economic Community (AEC) enable foreign workers to move across countries freely, and this poses threats to Indonesian workers given the fact that Indonesia is still lagging behind other ASEAN countries regarding education and productivity. Also, the latest data from the Central Bureau of Statistics (2017) survey shows that the number of employees decreased from 50.83 million in 2015 to 50.3 million in 2016. Finally, information technology is also responsible for the massive downsizing of organisations. The above issues may lead employees to generate proactive behaviour in the form of impression management to retain their employment in the current organisation (Bolino, Kacmar, Turnley \& Gilstrap, 2008: Grant \& Ashford, 2008).
Impression management is defined as the process when one tries to change how others see him/ herself (Leary \& Kowalski, 1990). Previously, research on impression management had been conducted at the individual and organisational levels (Rosenfeld, Giancalone, \& Riordan, 1995). The current study will focus on impression management at an individual level because we want to find an explanation of why employees exhibit impression management strategies at work. Impression management strategy was divided into two, namely positive impression management and negative impression management (Bolino, Long \& Turnley, 2016). In positive impression management, a person will try to make him/herself look good in front of other people. Positive impression management consisted of three strategies, namely self-promotion strategy that includes the ability of a person in making himself seen as competent, ingratiation strategy that occurs when a person uses praise to increase the possibility of himself to be liked by the intended person, and exemplification strategy that occurs when someone raises a behavior that makes him look like the ideal person in front of the target. On the other hand, in negative impression management, a person will try to make himself look bad in front of other people. 
Negative impression management involved the intimidation strategy used to create a full attribution of hazards, and a supplication strategy that allows one to advertise his or her limitations to look highly dependent on others. This study will only discuss the management of positive impressions because we want to see how far employees act to make themselves look good in front of the management and colleagues at work.

Previously, studies have found a variety of factors that triggered the emergence of impression management behaviour (Bolino et al., 2008; Leary \& Kowalski, 1990; Nagy, Kacmar \& Harris, 2010). Demographic factors that contributed to the emergence of impression management include gender, income, education (Sverke, Hellgren \& Naswall, 2006), and employee status (Naswall \& DeWitte in Sverke, Hellgren \& Naswall, 2006). In a review of the literature on impression management, Bolino et al. (2008) divided the factors causing impression management into two major groups, namely the dispositional (individual) and situational factors. Some examples of dispositional factors that have been studied are job strain, core selfevaluation, and political ability. Examples of situational factors are the employee's status (De Cuyper \& De Witte, 2010), selection process, the distance between the employee and his/her supervisor, the frequency of employee interaction and supervisor, supervisor's support, and unpleasant situations at the workplace such as job insecurity (Nagy, Kacmar \& Harris, 2011; Bolino et al., 2008; Huang, Zhao, Niu, Ashford \& Lee, 2013; Leary \& Kowalski, 1990).

In the current study, we will focus on job insecurity as a predictor of impression management. Job insecurity is defined as a person's perception of the powerlessness he or she experiences to sustain a job because of threats from the situation (Greenhalgh \& Rosenblatt, 1984). Huang, Niu, Liu and Ashford (2012) divide the work anxiety into two, the cognitive work unrest, which is the type of stress that comes from employees' perceptions of the possibility of change in work, and affective or emotional experience concerns arisen as a result of one's perception of change in work.

Several studies on the relationship between job insecurity and impression management found inconsistent results. For instance, Kang, Gold and Kim (2012) found that job insecurity negatively affected impression management. They argued the economic downturn that hit Korea since the 1980s might have affected how employees respond to job insecurity. On the contrary, Huang et al. (2013) found the relationship between job insecurity and impression management was moderated by motives of supervisors. De Cuyper, Schreurs, Elst and De Witte (2014) study found that the relationship between impression management and job insecurity was moderated by self-assessment.

Studies above indicated that the relationship between job insecurity and impression management is indirect. We suspect the perceived threatening situation, such as job insecurity, will encourage people to come up with certain coping strategy that may then lead to the impression management. Referring to the works of Lazarus and Folkman (1980), one of the individual difference variables often associated with the way a person overcomes stressors (such as job insecurity) is coping. Coping is defined as a change in cognition as well as behaviour that is used to address specific internal and external demands (Lazarus \& Folkman, 1984). Lazarus and Folkman (1980) divided coping into two types, namely problem-focused coping and emotion-focused coping. In the current study, we only used problem-focused coping because Lazarus (1984) contended that when one evaluates that he/she has a chance to change things for the better, then individuals tend to use problem-focused coping rather than emotion-focused coping. Problemfocused coping is a coping style that aims to change or eliminate the source of stressors (Lazarus \& Folkman, 1984). Examples of direct behavioural responses are applying for a new job, seeking social support, and discussing problems with supervisor.

As a result of the activation of problem-focused coping caused by job insecurity, individuals would attempt to engage in impression management tactics (Lazarus \& Folkman, 1980). This argument is based on findings in previous studies, which showed that problem-focused coping was associated with positive outcomes when the stressors were perceived as controlled (Ben-zur, 2009; Billings \& Moos, 1981; Pinquart \& Silbereisen, 2008; in Richter et al., 2013).

This research uses Transactional Stress Theory to explain the relationship between job insecurity,

problem-focused coping, and impression management (Lazarus \& Folkman, 1984). This theory suggests that the process of stress can be understood through the relationship of transactions between individuals and the environment. This transaction includes an individual's interpretation of his working situation, called cognitive appraisal, and has two stages: primary appraisal and secondary 
appraisal. During the primary assessment, the individual evaluates the specific situation he/she is experiencing and determines the importance of the condition to his/her well-being (Lazarus \& Folkman, 1984). The situation can be judged as insignificant, threatening, dangerous or challenging. In the context of job insecurity, individuals will tend to perceive potential job losses as a threat. When the situation has been assessed by the individual, where the primary judgment is followed by a secondary assessment, there is a possibility that the coping will be activated. Referring to the words of Lazarus and Folkman (1984), as long as one considers that the circumstances are threatening but manageable, he will activate problem-focused coping which in turn leads to impression management to overcome his job insecurity. Based on this theory, we predict that problem-focused coping will mediates the relationship between job insecurity and impression management.

\section{Methods}

Sample. Participants in this research were employees from various organisations in Jakarta. Participants were divided into two: permanent and non-permanent employees or contract-based employees. The selection criteria of participants were based on De Cuyper and De Witte (2010) which found that work status could affect a person's tendency to perform impression management. We sent out some 300 questionnaires to nine organisations in Jakarta by requesting direct permission to our acquaintances from March to May 2017. We employed temporal separation as suggested by Podsakoff et al. (2003) in which we separated the data collection of the predictors and outcome variables, and we developed a code to identify two separate questionnaires. First, we collected job insecurity and problem-focused coping data and asked our participants if they were willing to participate in the second survey. At the second data collection two weeks later, questionnaires were sent only to those who were willing to participate. We ensured participants that their participation is confidential and voluntary and that they may decide to quit anytime, Of the 297 questionnaires returned, we only used 286 questionnaires. The remaining 11 questionnaires were deleted because of incomplete responses.

Research Design. This study was a cross-sectional study in which we collected data in a certain period. However, to reduce the common method bias, we separated the data collection of predictor variables and outcome variable as suggested by Podsakoff et al. (2003).

Instrument and Measurement. We conducted translate-back translate process with the help of expert judgments to adapt the three measuring instruments to Bahasa Indonesia. We then conducted a pilot test on 41 employees who were actively working in the organisation. Based on our pilot study, the reliability coefficient of impression management, job insecurity, and problem-focused coping were

$.838, .804, .881$ respectively.

Impression management was measured using the Impression Management Scale made by Bolino and Turnley (1999). We used 12 items that measured positive impression management that included selfpromotion, ingratiation and exemplification. Participants will be provided with five choices of Likert scale ranging from " 1 = very unsuitable" to "5 $=$ very appropriate". An example of a statement of self-promotion tactics is "Speak proudly about your experience or education". An example of a statement from an ingratiation tactic is "Doing something nice for your colleagues to show you are friendly". An example of a statement of exemplification tactics is "Arrive at work on time to be seen as a dedicated person". The reliability analysis of this measuring instrument yields an alpha coefficient of .83 for selfpromotion, .72 for ingratiation tactics, and .71 for exemplification tactics.

Job insecurity was measured using DeWitte's Job 11item Insecurity Questionnaire (JIQ) (in Bosman, Buittendach \& Rothman, 2005). JIQ measures two aspects, namely cognitive job insecurity and affective job insecurity. Responses are in the form of Likerttype scale ranging from "1 = Strongly Disagree" to "5 $=$ Strongly Agree". An example statement of the cognitive aspect of job insecurity is "I think I will be fired shortly". The affective aspect of job insecurity is "I'm worried about the continuation of my career". Reliability analysis from JIQ yields alpha coefficient of .81 to .84 for job insecurity.

Problem-focused coping was measured using Coping Response Inventory - Adult Form (CRI - A) created by Moos (1993). This measuring tool consisted of 24 statements that measure approach coping responses (based on a problem-focused coping approach). Participants will be given four choices of answers in Likert scale from "not at all" to "often". An example of the statement is "I try to forget everything that happened". The reliability analysis of CRI-A yielded an alpha coefficient of .78 to .81 to identify problem- 
focused coping.We employed Hayes' PROCESS macro on Statistical Package for the Social Science (SPSS) to test the mediation hypothesis (Hayes, 2012).

\section{Results}

Based on 286 data processed, there were 158 males (55.2\%), and 128 females (44.8\%). A number of 104 (36.4\%) participants was between $19-29$ years, 123 (43\%) participants were between $30-40$ years, 51 (17.8\%) participants were between 41-51 years, and $8(2.8 \%)$ participants were between 52 -62 years.

Based on work status, 175 people are permanent employees (61.2\%), and 111 are contract employees (38.8\%). Based on the level of education, 25 participants have postgraduate degree $(8.7 \%), 151$ participants have undergraduate degree (52.8\%), 67 participants have college degree (13.6\%), 67 participants have high school degree $(23.4 \%)$, while 4 people fill the category "Others"(1.5\%).

Furthermore, based on length of work, $126(44.1 \%)$ participants have work experience of 1-5 years, 83 (29\%) participants have 5-10 years of work experience, while 75 (26.9\%) participants have more than 10 years of work experience.

Before testing the hypothesis, we first look at the correlations between our study variables.

Table 1.

Means, Standard Deviation, Coefficient Alphas, and Intercorrelations Between Variables
Table 1 presents the means, standard deviations, and correlations of all research variables. Gender, age, and employee's status are included in the table because they were found to influence impression management in the previous study by Naswall and DeWitte (in Sverke, Hellgren \& Naswall, 2006). In this study, results show that age and employee status are correlated with impression management $(\mathrm{r}=$ $.22, \mathrm{p}<.01),(\mathrm{r}=.14, \mathrm{p}<.001$, respectively $)$. Job insecurity is significantly and positively correlate with impression management $(\mathrm{r}=.11, \mathrm{p}<.01)$. Job insecurity is also negatively correlated with problem-focused coping $(\mathrm{r}=-.23, \mathrm{p}<.01)$. In addition, there is a significant and positive correlation between problem-focused coping of impression management $(\mathrm{r}=.11, \mathrm{p}<.05)$.

We then tested the mediation model using the regression method from Hayes on SPSS v. 20 by controlling the effect of these variables in our mediation model.

Table 2.

Mediation Effect of Problem-focused Coping on the Relationship between Job Insecurity and Impression Management

\begin{tabular}{|c|c|c|c|c|c|c|c|c|}
\hline \multicolumn{6}{|c|}{ Consequent } & \multicolumn{3}{|c|}{$\mathrm{Y}$ (Impression Management) } \\
\hline \multicolumn{2}{|l|}{ Predictors } & Coeff & SE & p & & Coeff & SE & $\mathbf{p}$ \\
\hline $\begin{array}{l}\text { X (Job } \\
\text { Insecurity) }\end{array}$ & a & -0.128 & 0.0357 & 0.0004 & $c^{\prime}$ & 0.1427 & 0.0791 & 0.723 \\
\hline $\begin{array}{l}\text { M (Problem- } \\
\text { focused Coping) }\end{array}$ & & - & - & - & $\mathrm{b}$ & 0.3007 & 0.1291 & 0.0205 \\
\hline $\mathrm{C} 1$ (Age) & $\mathrm{f}_{1}$ & -0.046 & 0.0024 & 0.0557 & $\mathrm{~g}_{1}$ & -0.0157 & 0.0052 & 0.0027 \\
\hline $\begin{array}{l}\text { C2 (Employee's } \\
\text { Status) }\end{array}$ & $\mathrm{f}_{2}$ & 0.0669 & 0.0428 & 0.1194 & $\mathrm{~g}_{2}$ & 0.0489 & 0.0933 & 0.6008 \\
\hline Constant & & $\begin{array}{l}3.7814 \\
\mathrm{R}^{2}=0.0 \\
\mathrm{~F}(3,282) \\
\mathrm{p}<0.01\end{array}$ & $\begin{array}{l}0.1327 \\
1 \\
7.2859\end{array}$ & 0 & & $\begin{array}{l}1.8517 \\
\mathrm{R}^{2}=0.0 \\
\mathrm{~F}(4,281) \\
\mathrm{p}<0.01\end{array}$ & $\begin{array}{rl} & 0.5666 \\
7 & 7 \\
= & 6.0873 ; \\
\end{array}$ & 0.0012 \\
\hline
\end{tabular}

\begin{tabular}{|c|c|c|c|c|c|c|c|c|}
\hline & $\mathbf{M}$ & SD & 1 & 2 & 3 & 4 & 5 & 6 \\
\hline 1. Gender & 1.4 & 0.4 & - & & & & & \\
\hline 2. Age & 33.7 & 8.3 & $-0.1 * *$ & - & & & & \\
\hline $\begin{array}{l}\text { 3.Employees's } \\
\text { Status }\end{array}$ & 2.3 & 0.4 & 0.0 & $-0.4^{* *}$ & - & & & \\
\hline 4. JI & 2.2 & 0.5 & -0.8 & $-0.1^{*}$ & $0.31 * *$ & $(-0.8)$ & & \\
\hline 5. PFC & 3.2 & 0.3 & 0.0 & $-0.0^{*}$ & $-0.11 *$ & $-0.2 * *$ & $(-0.7)$ & \\
\hline 6. IM & 2.6 & 0.6 & -0.6 & $-0.2 * *$ & $0.14 * *$ & $0.1^{*}$ & $0.1^{*}$ & $(-0.8)$ \\
\hline
\end{tabular}

$\mathrm{N}=286$.

$*$ significant on $p<0,05 ; * *$ significant on $p<0,01$

Note:

Age was measured in year. Gender was dummy-coded $(1=$ male, 2 = female). Employment status was dummy-coded ( 1 = permanent, 2 = contract. Cronbach's Alpha was shown in diagonal. JI = Job insecurity, PFC = Problem-focused coping, $\mathrm{IM}=$ Impression management.
The results show that job insecurity does not have significant effect on impression management (total effect $=.1042, \mathrm{SE}=.0779, \mathrm{p}=.1825,95 \%$ CI $[-$ $.0493, .2576])$. The results show that problemfocused coping fully mediates the relationship between job insecurity and impression management, as the indirect effect of job insecurity on impression management through problem-focused coping is significant (indirect effect $=-.0385, \mathrm{SE}=.0212, \mathrm{CI}$ $[-.0932,-.0060])$. This support our hypothesis, implying that job insecurity is the distal variable of impression management, and problem-focused coping is the proximal variabel of impression management. 
Below is the research model:

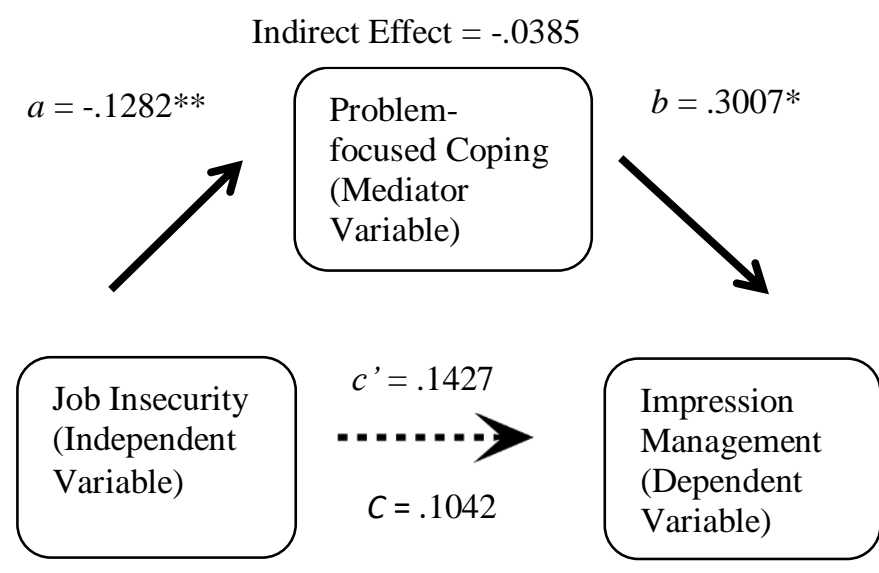

Figure 1. Mediation Model of Research Results

\section{Discussion \& Conclusion}

Discussion. The main purpose of this study is to examine the mediating effect of problem-focused coping on the relationship between job insecurity and impression management.We found that problem-focused coping mediated the relationship between job insecurity and impression management. However, contrary to our expectation, we found that job insecurity reduced the ability of individuals' problem-focused coping and in turn decreased their effort to perform impression management.These findings support previous job insecurity research by Scheurs (in De Cuyper et al., 2014) who found that the presence of job insecurity led employees to avoid matters related to their work. In this case, we argue that it is possible that individuals with high job insecurity will activate emotional-focused coping instead of problem-focused coping. We suggest future research to examine this avenue.

Our findings suggested that the transactional stress theory was not appropriate to explain the results of this study. We argue that perhaps psychological safety theory might explain the relationships better than transactional stress theory. Psychological safety is defined by Kahn (1990) as a sense of security that a person feels to show his ability without any fear of another's bad judgment of his/her image, status, or career. In the theory of psychological safety, it is said that generally a person will contribute in the workplace when he/she is faced with potential threats that can harm themselves (Argyris in Edmonson, 1999). Dutton (in Edmonson, 1999), added that the presence of threats in organizations can limit a person's desire to engage in problemsolving activities. The presence of psychological safety can decrease a person's likelihood to think about the negative consequences of his/her contribution, so he/she feels safer and motivated to contribute to the work environment (Edmonson, 1999). Referring to the theory of psychological safety, the relationship between impression management, job insecurity and problem-focused coping can be described as follows: When confronted with threatening situation which is absent from psychological safety such as job insecurity, one will feel that direct behavioral responses can threaten his/her image. This in turn will inhibit their possibility to activate problemfocused coping which in turn may hinder the tendency to use impression management.

Our study is not without limitations. As our study uses cross-sectional design, this limits our ability to infer causal relationship between variables. We suggest future research to employ longitudinal study, in which variables are examined over some period of time, as this method is more robust than cross-sectional design in terms of the inference of causal relationships. Moreover, it would also be interesting to examine variations in these variables over time, since it is possible that the feeling of job insecurity, the activation of problem-focused coping, and the impression management behavior to change over time.

Conclusions. Based on our study, we can conclude that problem-focused coping fully mediates the relationship between job insecurity and impression management. However, contrary to our expectation, perceived job insecurity does not lead to the activation of problem-focused coping and then impression management behaviors. We found that perceived job insecurity weakened individuals' ability to activate problem-focused coping, and in turn led to reduced willingness to perform impression management.

\section{References}

Adnan, A., \& Latif, K.I. (2013). Impression management and its impact on employee promotion. Abasyn Journal of Social Sciences, 6, 1-13.

Central Bureau of Statistics. (2017). December 2016: Inflation raise by 0.42 percent. Retrieved from https://www.bps.go.id/brs/view/id/1284

Bolino, M.C., Kacmar, K.M., Turnley, W.H., \& Gilstrap, J.B. (2008). A multi-level review of impression management motives and behaviors. Journal of Management., 34, 1080-1108. doi: 10.1177/0149206308324325 
Bolino M. C., Long D. M., Turnley W. H. (2016). Impression management in organizations: Critical questions, answers, and areas for future research. Annual Review of Organizational Psychology and Organizational Behavior, 3, 377-406.

Bosman, J., Buitendach, J.H., \& Rothman, S. (2005) Work locus of control and dispositional optimism as antecedents to job insecurity. SA Journal of Industrial Psychology, 31(4), 17-23. doi: 10.4102/sajip.v31i4.217

Daeng, S. (2016). This is the serious impact from the declining oil prices in the world. Retrieved from http://bisnis.liputan6.com/read/2431727/opini-as-ini-thehealthy-prime-the-price-price-free-world

De Cuyper, N., De Witte, H., Eist, T.V, \& Handaja, Y. (2010). Objective threat of unemployment and situational uncertainty during a restructuring: Associations with perceived job insecurity and strain. Journal of Business and Psychology, 25, 75-85. doi: 10.1007/sl 0869-009-9 128-y

De Cuyper, N., \& De Witte, H. (2010). Temporary employment and perceived employability: Mediation by impression management. Journal of Career Development, 37, 1-18. doi: $10.1177 / 0894845309357051$

De Cuyper, N., Schreurs, B., Vander Elst, T., Baillien, E., \&De Witte, H. (2014). Exemplification and perceived job insecurity: Associations with self-rated performance and emotional exhaustion. Journal of Personnel Psychology, 13, 1-10. doi: 10.1027/1866-5888/a000099

Edmonson, A. (1999). Psychological safety and learning behavior in work teams. Administrative Science Quarterly, 44, 350-383. doi: 10.2307/2666999

Grant, A.M. \& Ashford, S.J. (2008). The dynamics of proactivity at work. Research in Organizational Behavior, 28, 3-34. doi:10.1016/j.riob.2008.04.002

Greenhalgh, L. \& Rosenblatt, Z. (1984). Job insecurity: Toward conceptual clarity. Academy of management review, 9, 438-448. doi: 10.5465/AMR.1984.4279673

Hayes, A. F. (2012). PROCESS: A versatile computational tool for observed variable mediation, moderation, and conditional process modeling. Retrieved from http://www.afhayes.com/public/process2012.pdf.

Hayes A. F. (2013). Introduction to mediation, moderation, and conditional process analysis: A regression-based approach. New York: Guilford Press.

Huang, G., Zhao, H.H., Niu, Z., Ashford, S., \& Lee, C. (2013). Reducing job insecurity and increasing performance ratings: Does impression management matter?. Journal of Applied Psychology, 98, 1-11. doi: 10.1037/a0033151

Kacmar, K.M., Harris, K.J, \& Nagy, B.G. (2007). Further validation of the bolino and turnley impression management scale. Journal of Behavioral and Applied Management, 3, 16-32.
Kahn,W.A. (1990). Psychological conditions of personal engagement and disengagement at work. Academy of Management Journal, 33, 692-724. doi: 10.2307/256287

Kang,D., Gold, J, \& Kim, D. (2012). Responses to job insecurity: The impact on discretionary extra-role and impression management behaviors and the moderating role of employability. Career Development International, 17, 314-332. doi: 10.1108/13620431211255815

Lazarus, R.S \& Folkman, S. (1980). An analysis of coping in a middle-aged community sample. Journal of Health and Social Behavior, 21, 219-239. doi: 10.2307/2136617

Lazarus, R.S. \& Folkman, S. (1984). Stress, appraisal and coping. New York: Springer Publishing Company.

Leary, M.R., \& Kowalski, R.M. (1990). Impression management: A literature review and two-component model. Psychological Bulletin, 107, 34-47. doi: 10.1037/0033-2909.107.1.34

Mao, P. (2014). A multilevel research of antecedent and consequence of impression management in service industry: Service climate as the moderator. Journal of Tourism and Recreation, 5, 364-373.

Moos, R.H. (1993). Coping responses inventory: CRI-adult form professional manual. Odessa: Psychological Assessment Resource Inc.

Nagy, B., Kacmar, M., Harris, K. (2011). Dispositional and situational factors as predictors of impression management behaviors. Journal of Behavioral and Applied Management, 12, 229-245.doi: 10.1016/j.jvb.2003.09.002

Podsakoff, P.M., MacKenzie, S.M., Lee, J., \& Podsakoff, N.P. (2003). Common method variance in behavioral research: A critical review of the literature and recommended remedies. Journal of Applied Psychology, 88, 879-903.

Richter, N., Naswall, K., Cuyper, N.D., Witte, H.D., \& Hellgren, J. (2013). Coping with job insecurity: Exploring effects on perceived health and organizational attitudes. Career Development International, 18, 484-502. doi: 10.1108/CDI-06-2013-0081

Rosenfeld, P. R., Giacalone, R. A. \& Riordan, C. A. (1995). Impression management in organizations: Theory, measurement, and practice. New York: Routledge.

Sverke M., Hellgren J., and Näswall K. (2002) No security: A meta-analysis and review of job insecurity and its consequences. Journal of Occußational Health Psychology, 7, 242-264. doi:10.1037//1076-8998.7.3.242

Sverke M., Hellgren J., and Näswall K. (2006) Job insecurity: A literature review (SALTSA Report No. 1:2006). Stockholm: National Institute for Working Life.

Weiss, B., \& Feldman, R.S. (2006). Looking good and lying to do it: Deception as an impression management strategy in job interviews. Journal of Applied Social Psychology, 36, 1070-1086. 